\title{
CONFIRMATION OF TAXONOMIC STATUS OF BLACK YEAST-LIKE FUNGUS BY THREE GENE PHYLOGENY
}

\author{
T. O. Kondratiuk ${ }^{1}$, S. Y. KondratyuK ${ }^{2,3}$, M. V. Khimich ${ }^{1}$ \\ T. V. Beregova ${ }^{1}$ and L. I. Ostapchenko ${ }^{1}$ \\ ${ }^{1}$ Institute of Biology, Scientific Educational Centre, Taras Shevchenko National University of \\ Kiev, Volodymyrska str.64/13, 01601 Kyiv, Ukraine; E-mail: takbiofak@ukr.net \\ ${ }^{2}$ M. H. Kholodny Institute of Botany, Tereshchenkivska str. 2, 01004 Kyiv, Ukraine \\ ${ }^{3}$ Korean Lichen Research Institute, Sunchon National University \\ Sunchon 540-742, Republic of Korea
}

(Received 15 May, 2016; Accepted 10 July, 2016)

Status of black melanin-containing yeast-like fungus Exophiala alcalophila isolated from microorganism complex of hermetic damaged in conditions of indoor high humidity in Kiev, Ukraine is proved by combined phylogenetic analysis based on sequences of the internal transcribed spacer 1 (ITS1), the $5.8 \mathrm{~S}$ gene and the internal transcribed spacer 2 (ITS2) nrDNA, beta-tubulin gene and translation elongation factor 1-alpha gene. Sequences of the mentioned genes of Ukrainian specimen of E. alcalophila are for the first time submitted to the GenBank.

Key words: Exophiala alcalophila, hermetic, high humidity, microorganism complex, phylogenetic analysis

\section{INTRODUCTION}

"Black yeast fungi" is a group of fungi that is quite heterogeneous from taxonomic and phylogenetical point of views, but having in common melanised cell walls and the formation of daughter cells by yeast-like multilateral or polar budding. Exophiala is an anamorphic genus defined by annellidic conidiogenesis producing slimy heads of conidia, and a phylogenetical affiliation to the ascomycete order Chaetothyriales (Sterflinger 2006). Nearly all species are characterised and recognisable within the order by their production of budding cells, and the yeast/hypha transition mostly proceeds via torulose hyphae (de Hoog et al. 2011). Where they are known, teleomorphs belong to Capronia.

Representatives of black yeast genus Exophiala are common in nature, on wood decomposing in soil and in water (Sutton et al. 1998). Wet cells like 
bathrooms, sinks, kitchens and saunas were described as novel niches for adaptation of human pathogens (Hamada 2013, Hamada and Abe 2010, Lian and de Hoog 2010, Nishimura et al. 1987, Zalar et al. 2011). Bathwater and sludge of bathroom drainpipes are important habitats for members of the genus Exophiala (Hamada and Abe 2010, Matos et al. 2002, Nishimura et al. 1987). They were also recorded on the marble and various rocky substrates, and as members of the communities damaging various building materials, as well as on acrylic hermetic in bathrooms, from drinking water, etc. (Hageskal et al. 2006, Kondratyuk 2010).

Some representatives of the genus Exophiala are categorized to the Biosafety Level 2 (BSL) risk group, introduced by various international organisations (Gunde-Cimerman and Zalar 2011, Ozerskaya et al. 2007). Some taxa of this genus are potential pathogens and opportunists, some species can cause serious illness in healthy, immunocompetent people (de Hoog et al. 2000, Kantarcloglu and de Hoog 2004, Rimawi et al. 2013). The appearance of human skin infections suggested to be connected with the presence of black yeasts in the rooms, including the bathrooms (i.e. sensu "water systems" rooms) (Lian and de Hoog 2010). These fungi thought to be also associated with many kinds of diseases of wildlife, including fish, marine toads, turtles, shellfish (de Hoog et al. 2011).

Considering the ability of black yeast-like fungi of the genus Exophiala remain viable and to form different morphological types in the conditions of joint influence a wide range of temperatures, $\mathrm{pH}$ and salt content of they are often classified as polyextremotoletant fungi (Döğen et al. 2013, Hamada and Abe 2010, Zalar et al. 2011). These fungi are rather dangerous, because they can grow at high temperatures and are capable of colonising warm-blooded organisms (Gostincar et al. 2011).

Black yeast-like fungus Exophiala alcalophila Goto et Sugly was found in microorganism complex of hermetic damaged in conditions of indoor high humidity in Kyiv, Ukraine (Kondratyuk 2010, 2013). It was recorded after results of phylogenetic analysis based on sequences of ITS1/ITS2 (Kondratyuk et al. 2013). However, submission ITS1/ITS2 sequence of Ukrainian specimens of this taxon to the GenBank was postponed till sequences of beta-tubulin (BT2), actin (ACT1) and translation elongation factor 1-alfa (TEF-1) gene from the same fungus were obtained.

A recently published paper of de Hoog and colleagues (de Hoog et al. 2011) may serve as extremely important handbook in taxonomic revision of this group of black yeast-like fungi, while previous data on morphology and molecular characters of Exophiala species were scattered in medical, veterinary and ecological literature (see also Table 1). These authors have provided reliable data on the type collections of major portion of species of the genus 
Exophiala, which allow identifying representatives of this genus after multigene phylogeny. There are even two or three gene sequences of the same gene of the same taxon based on the same CBS cultures submitted to the GeneBank by various authors in different time (see also Table 1 ).

After combined phylogenetical analysis based on ITS, ACT1, BT2 and TEF-1 sequences (after de Hoog et al. 2011) Exophiala alcalophila belongs to the Exophiala angulospora complex, which is positioned in out-position to the SSU Exophiala salmonis-clade, type clade of the genus Exophiala.

The aim of this paper is to provide complete set of data on molecular identification of Ukrainian specimens of Exophiala alcalophila, to present results of combined phylogenetical analysis based on ITS1/ITS2 nrDNA, BT2 and TEF-1 gene sequences and to submit these data to GenBank. To check the position of the Ukrainian specimen all known taxa of the SSU Exophiala salmonis-clade (sensu de Hoog et al. 2011), as well as taxa of the Exophiala angulospora complex for which data on ITS, BT2 and TEF-1 sequences are hitherto available from the GenBank were included in our combined phylogenetical analysis. Unfortunately our attempt to get ACT1 gene sequence from Ukrainian specimen of Exophiala alcalophila was unsuccessful; it is why data on this gene were not included in the combined phylogenetical analysis.

\section{MATERIAL AND METHODS}

\section{Strains and culture conditions}

Standard microbiological methods of microorganism cultivation in agar nutrient media (Malt extract agar (Merck, Germany, containing peptone); Malt extract agar (Heimedia, India, without peptone); Nutrient agar (Sigma); Czapek-Dox agar (CZD); Sabouraud agar (HiMedia); Potato dextrose agar (PDA); Synthetic medium SNA, depleted in nutrients (i.e. synthetischer nährstoffarmer agar), which were prepared in accordance with specifications, set out in Samson et al. (2004); and liquid media as Potato-glucose broth containing 2\% glucose (PGB) (Samson et al. 2004); Glucose-yeast-peptone medium (GPY, Sigma, USA); and Meat-peptone broth (MPB)) were used. Furthermore the following original and modified media, i.e.: MPB with $2 \%$ glucose; $10 \%$ sucrose solution; Potato broth without glucose; PGB with $2 \%$ and $10 \%$ glucose; GPY (containing 10\% glucose, $1 \%$ peptone, $1 \%$ yeast extract); and GP (glucose-peptone medium containing 10\% glucose, and $1 \%$ peptone) were also used within these studies.

Photographing fungal specimens performed using microscope Carl Zeiss Primo Star company (Germany) and Camera Scope Tek, m. Etrek DCM-510, at magnification $\times 400$. The length and width of the cells was measured by the 
morphometric computer program AxioVision 4.8 (Carl Zeiss). Morphometric data (length and width of cells), the intensity of budding were calculated with the usage of arithmetic mean and standard deviation using Statistica 12. The reliability of differences was determined using Student $t$-test, significance level $\mathrm{r} \leq 0.05$. To understand the morphological features of Exophiala alcalophila additionally used scanning electron microscopy (SEM JSM-6060 LA, Japan).

Ukrainian strain from hermetic has been isolated from microorganism complex in conditions of indoor high humidity in Kyiv, Ukraine in 2010 by a pour-plate method. Sampling location was black outgrowth on surface of hermetic layer between bath-cabin and wall of bathroom of private flat in Kyiv city (Kondratyuk 2010, 2013). Strains were maintained on MEA (2\% Malt Extract Agar) or PDA (Potato-Dextrose Agar) slants at $4{ }^{\circ} \mathrm{C}$.

Culture obtained and supported in "Institute of Biology" Educational and Scientific Centre of Taras Shevchenko National University of Kyiv (FCKU 304).

Identification of pure cultures after morphological characters was done with applying traditional manuals (de Hoog et al. 2000, 2011, Sutton et al. 1998, 2001). Data on morphology of colonies, conidiogenous structures were compared with recent publications (de Hoog et al. 2011, Lian and de Hoog 2010).

Prior to analysis, small pieces from mature colonies were suspended in $4.5 \mathrm{ml}$ sterile water to obtain conidial suspensions. Aliquots of $0.5 \mathrm{~mL}$ were plated on liquid media in culture plates and incubated at $24^{\circ} \mathrm{C}$ for $2-4$ weeks. Physiological data on cultures studied were obtained using automated microbiological analyser Vitek 2 Compact (BioMerieux, France). Appropriate special ID-cards (YST-cards - for yeasts and filamentous fungi) were used. The special medium Phenol red dextrose broth (HiMedia) was additionally applied for detection of the ability to ferment glucose, as well as Nitrate broth (HiMedia) for the capacity to restore nitrates in nitrites.

Genomic DNA was isolated using the NucleoSpin Plant II DNA extraction kit according to the manufacturer's protocol for DNA from fungi (Macherey-Nagel, Düren, Germany). The nuclear ribosomal RNA gene region including the internal transcribed spacers 1 and 2 and the $5.8 S$ subunit (ITS) were amplified using the primers ITS1F (Gardes and Bruns 1993) and ITS4 (White et al. 1990). Amplification was performed using CFX 96 Real-Time PCR Detection System (BioRad). The fluorescent dye SYBR Green was used to stain DNA.

Sequences derived in this study were lodged at GenBank KX793104KX793106.

DNA extraction and amplification methods were outlined by de Hoog et al. (2011). Nuclear DNA was isolated from fungus mycelium cultivated on PDA with the usage of Ultra Clean TM Microbial DNA isolation Kit (MoBioLaboratories, inc. Solana Beach, CA, USA). Fragments of rDNA were ampli- 
fied using the universal primers V9G and LS266 for rDNA ITS, Ef1-728F and Ef1-986R for TEF-1, Bt2a and Bt2b for BT2 for ITS, TEF and BT consequently (de Hoog et al. 2011).

\section{Alignment and phylogenetical reconstruction}

For genealogical concordance analysis, three genes ITS, TEF-1 and BT2 were first analysed separately. Alignment was performed automatically and adjusted iteratively by hand with BioNumerics v.4.61. MP, ME and LP analysis implemented in PAUP v. 4.0b10 were used. Consequently taxa of the SSUbased Exophiala salmonis-clade (sensu de Hoog et al. 2011) were included in a combined ML analysis based on ITS, TEF-1 and BT2 gene sequences. Strains analysed are listed in Table 1.

\section{RESULTS}

\section{Cultural morphological characters}

Brownish black colonies of Exophiala alcalophila to $20-25 \pm 1 \mathrm{~mm}$ in diam. were observed after $7-10$ days at $+26 \pm 2{ }^{\circ} \mathrm{C}$ on MEA (Figs 1, 3-5, 8-12), PDA (Figs 6-7), and Sabouraud agar (Figs 2, 13). The mucilage-like colonies with oily glance were observed in Sabouraud agar.

Formation of true hyphae was observed on MEA medium, PDA, CZD, and SNA media. Cell clusters and cell chains were formed on PDA medium, and dominance of almost spherical (to 3-6 $\mu \mathrm{m}$ diam.) or oval (2.5-3 $\times 3-5.8$ $\mu \mathrm{m})$ cells was found on Sabouraud agar.

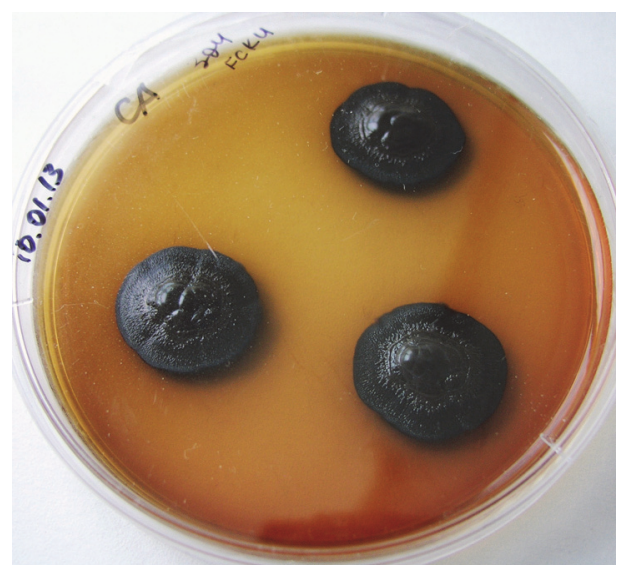

Fig. 1. General habit of Exophiala alcalophila FCKU 304 colony on MEA medium

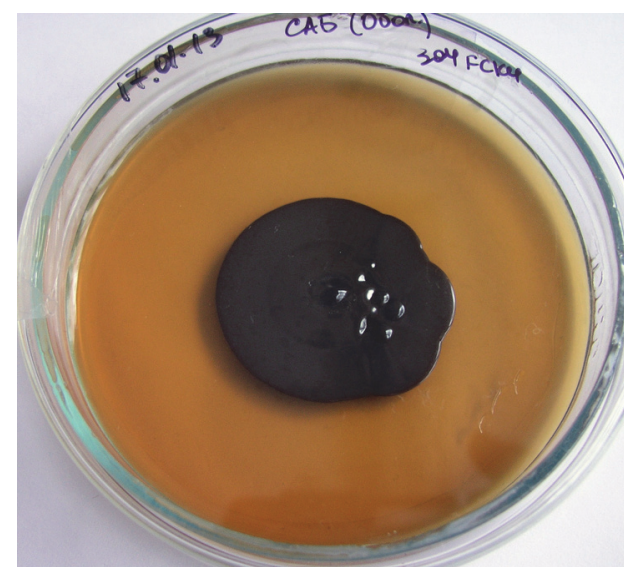

Fig. 2. General habit of Exophiala alcalophila FCKU 304 colony on Sabouraud agar 


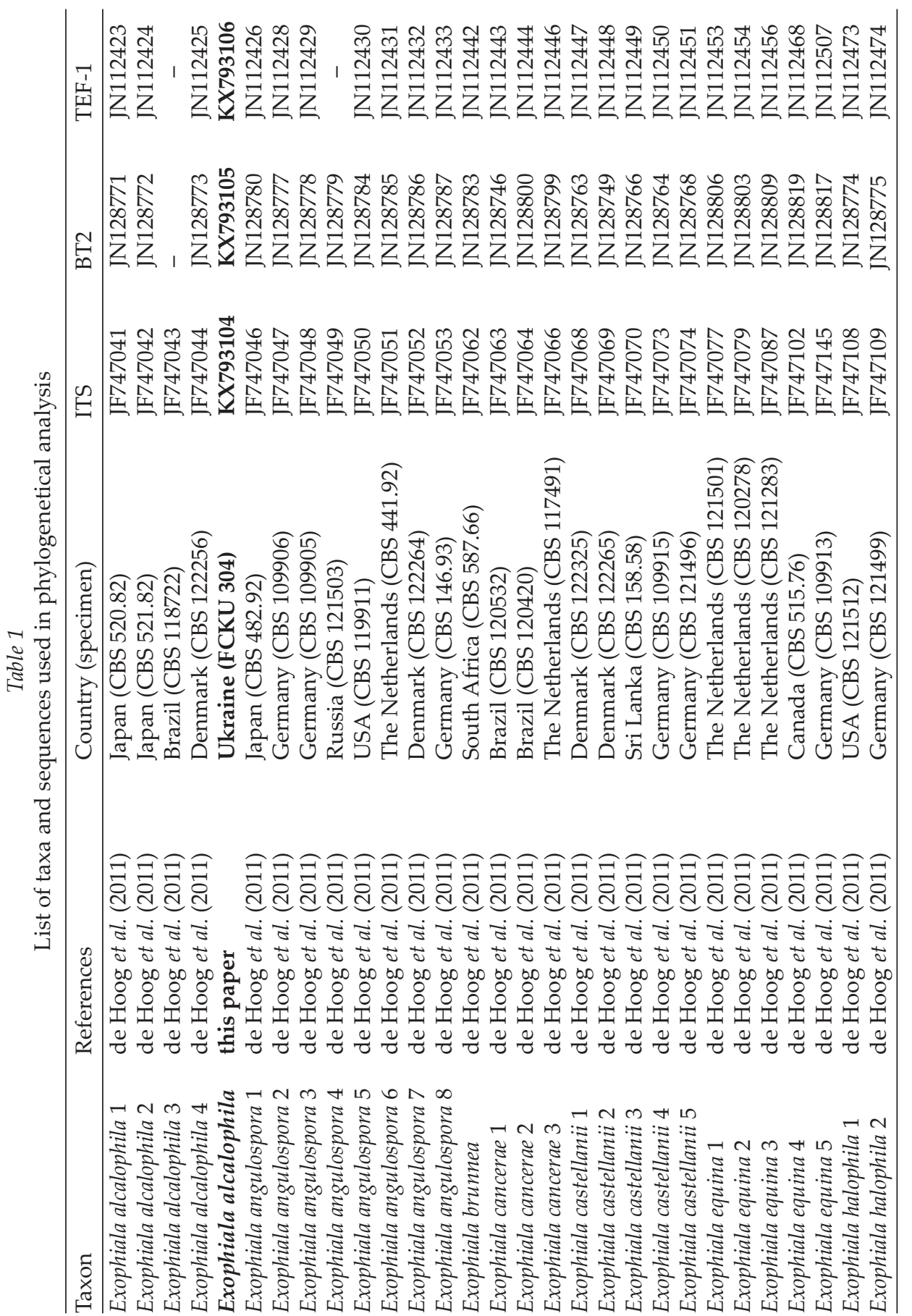




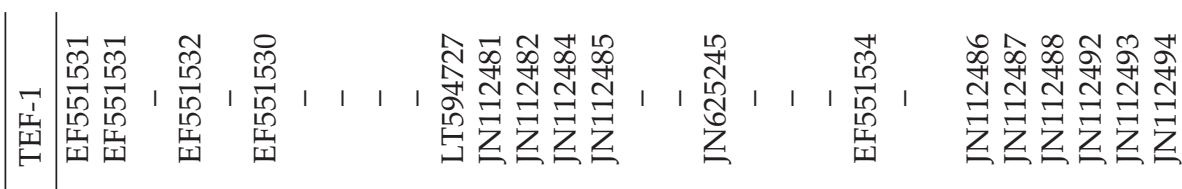

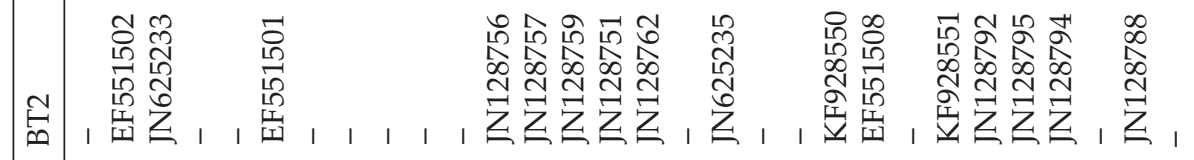

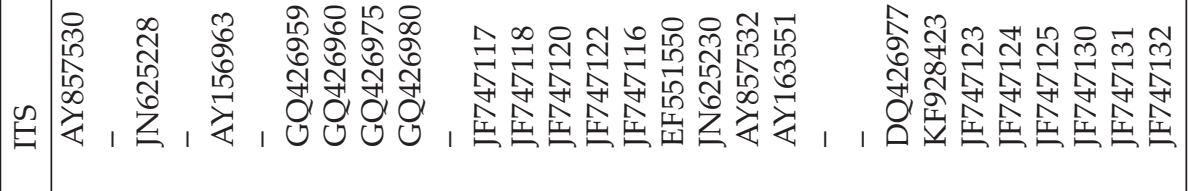

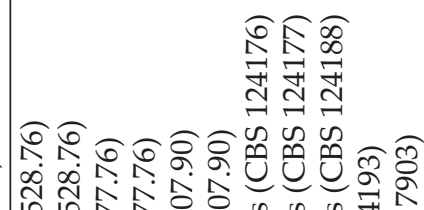

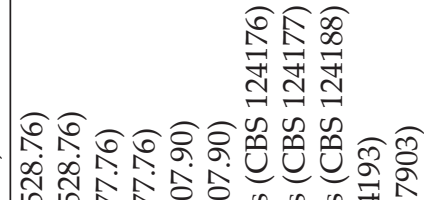

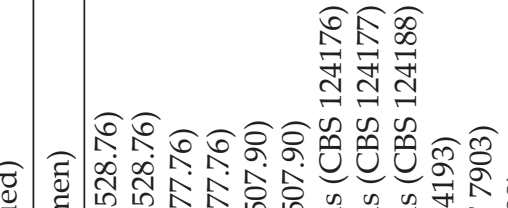

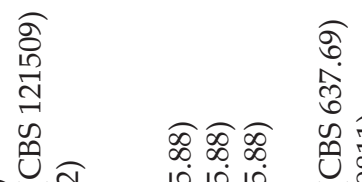

3.

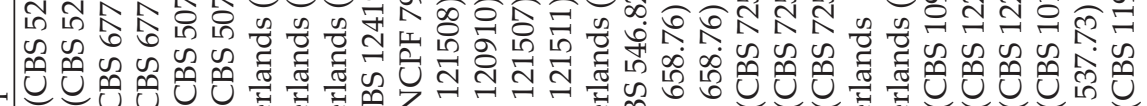

F

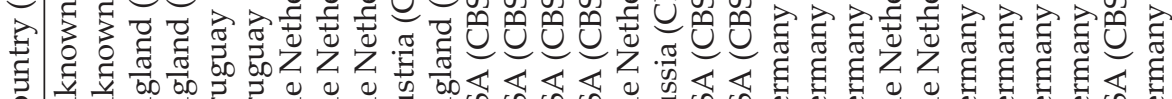

ठ

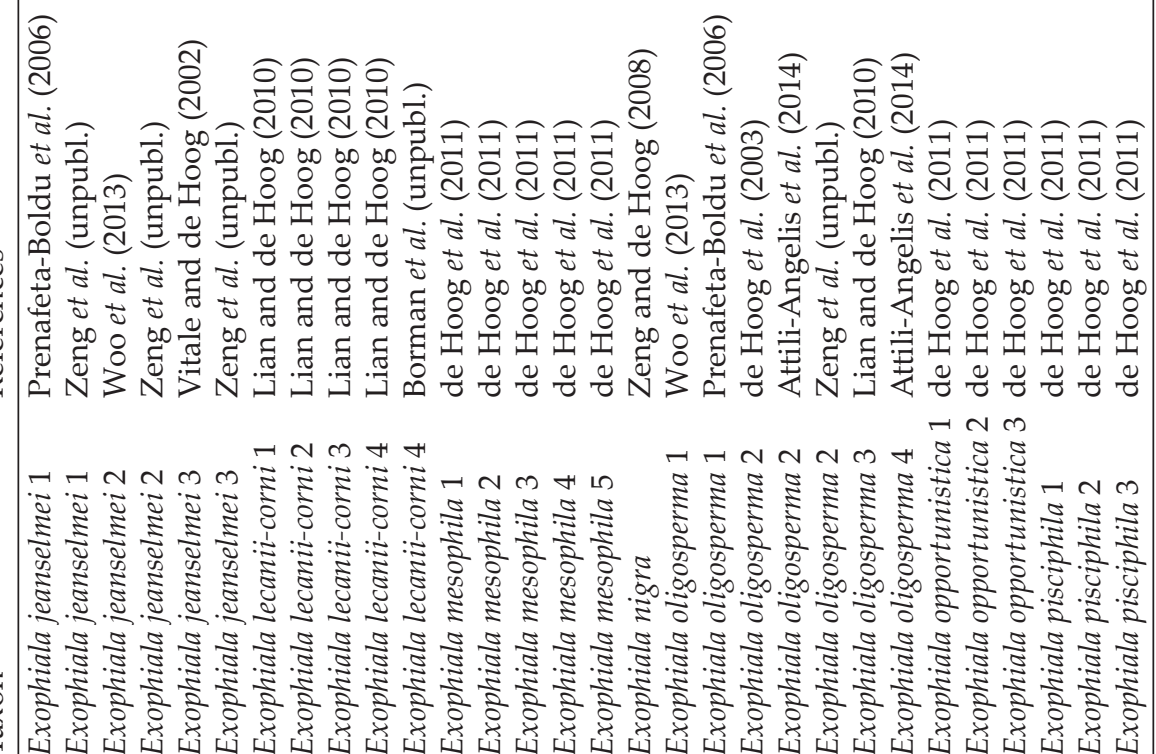



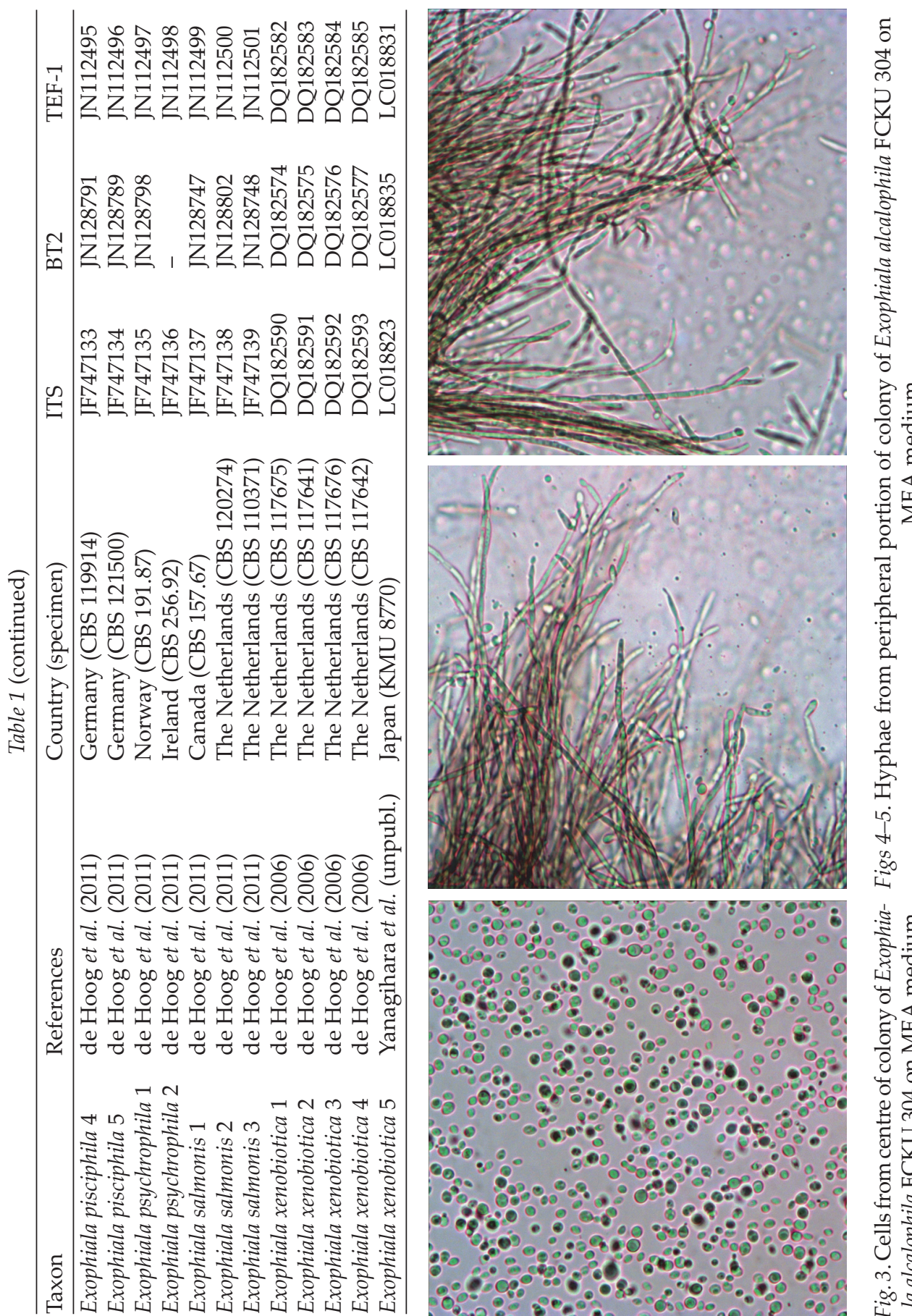

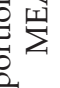

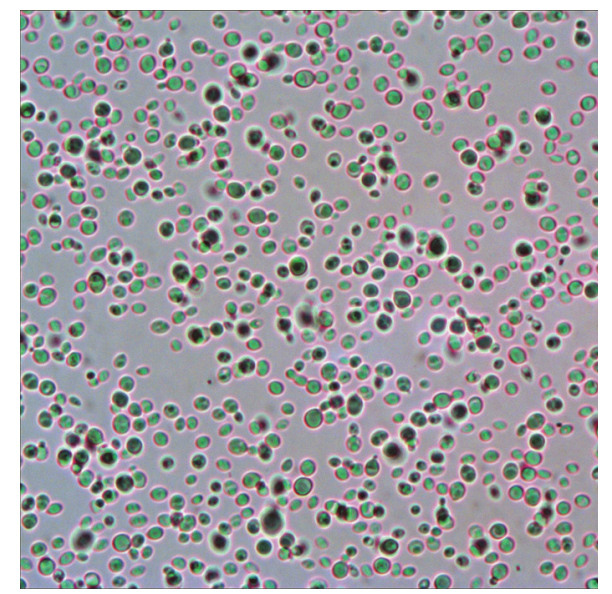

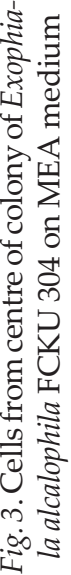



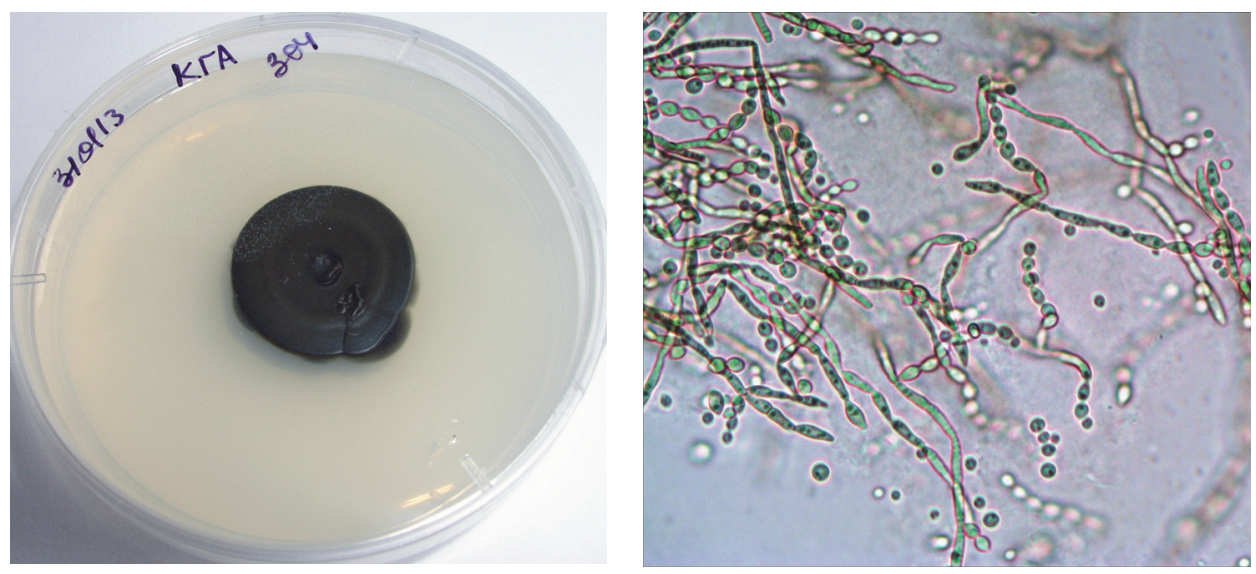

Figs 6-7. General habit of Exophiala alcalophila FCKU 304 colony on PDA medium (left); conidial apparatus, conidia, budding cells and torulose hyphae of Exophiala alcalophila FCKU 304 colony on PDA medium (7th day of cultivation) (right)

The yeast phase of Exophiala alcalophila found to be dominated on the MEA and PDA media during the first week, while hyphal morphotype is observed at the edges of colony later. However, it should be emphasised that the dominance of any morphotype (yeast or mycelium) of Exophiala alcalophila is very unstable characters. The structure of colonies on solid media is quite different from those in liquid ones (MEA, PDA and Sabouraud agar).

It is very characteristically radiating / radially ramified on SNA medium (Fig. 14), and more compact and loosing lustre and edges becoming somewhat irregular in other solid media (i.e.: CZD, on CZD with low-carbon content $(0.1 \%))$ (Fig. 15).

Thus, in contrast to data of de Hoog et al. (2011), where Exophiala alcalophila formed hyphal structures only on MEA medium, formation of hyphal
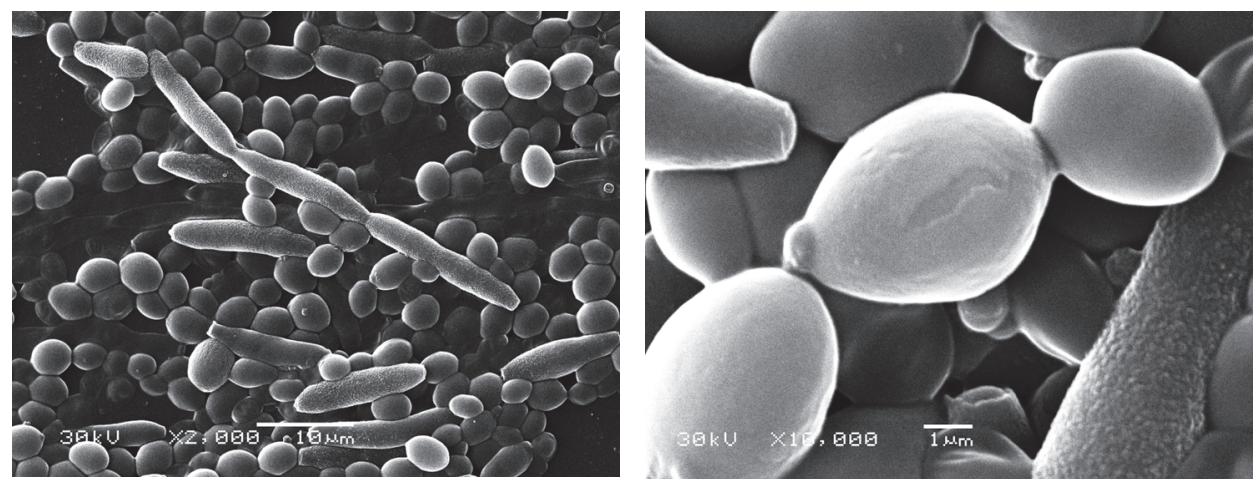

Figs 8-9. Budding cells and conidia of Exophiala alcalophila FCKU 304 on MEA medium 


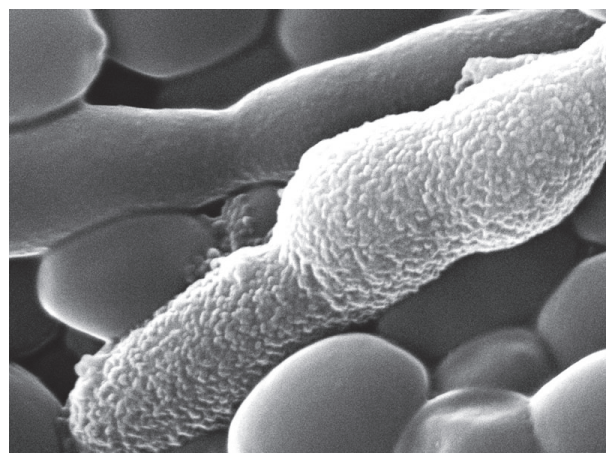

Fig. 10. Torulose hyphae of Exophiala alcalophila FCKU 304 on MEA medium

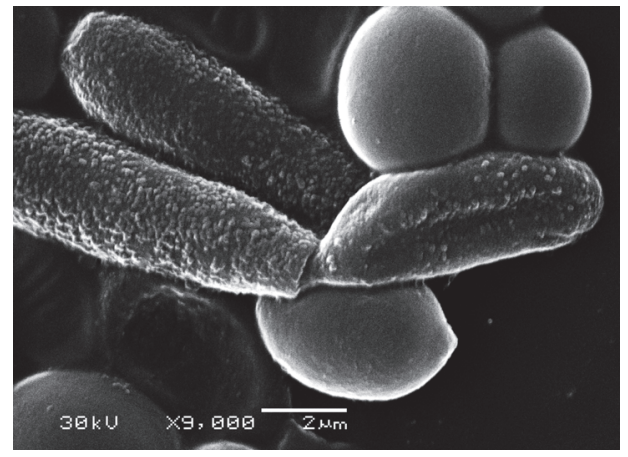

Fig. 11. Terminal conidia formation of Exophiala alcalophila FCKU 304 on MEA medium

morphotype in our case was observed also on PDA, MPB, CZD and CZD with low-carbon $(0.1 \%)$ content, as well as under influence of biocides and under influence of plant essential oils (i.e.: Abies, Foeniculum, Juniperus, Lavandula, Melaleuca, Mentha, Origanum, Pelargonium, Pinus, Syzygium (Caryophyllus) and Thymus), as well as polyhexamethylene guanidine (Kondratyuk and Kalinichenko 2014, 2015).

Exophiala alcalophila found to be well developed on liquid media tested. Morphological exchanges of Exophiala alcalophila (i.e. formation of septate hyphae, moniliform annelophores widened at the basis, with urn-like (attenuated) ends were observed on MPB. Exchange of medium colour (medium becoming dark grey almost black colour probably owing to abundant synthesis of melanin) additionally to slight distraction was found in conditions of $E$. alcalophila growth on low $\mathrm{pH}$ (to 2-3.5) of liquid media GPY, GP and 10\%

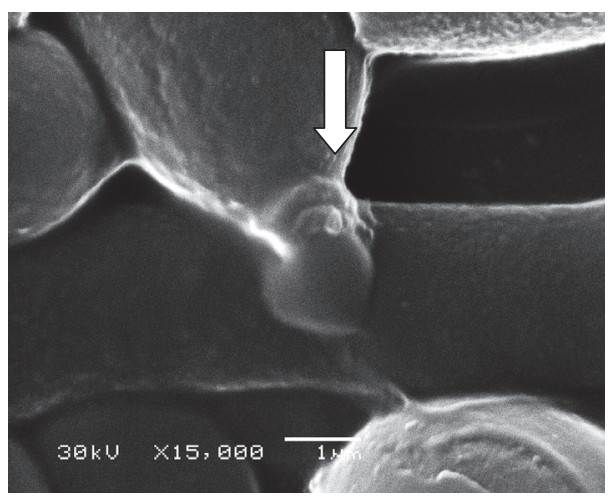

Fig. 12. Intercalary conidia formation in Exophiala alcalophila FCKU 304 (on MEA medium); arrow shows short annelation zone

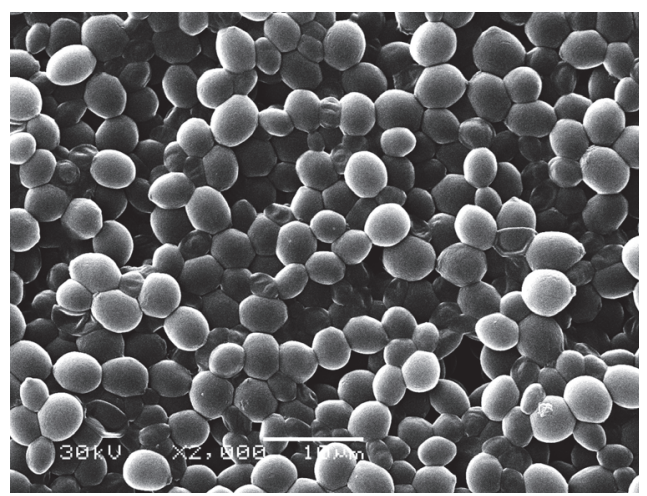

Figs 13. Budding cells of Exophiala alcalophila FCKU 304 on Sabouraud agar 
solution of dextrose. Examined specimen of E. alcalophila weakly fermentates D-glucose with minor gas formation. It shows ability to assimilation of LeuA, GLYLa, 2KGa, and XLTa, as well as urease formation. E. alcalophila assimilate (assimilates) nitrates (nitrate converts to nitrite). No growth of E. alcalophila at $+37^{\circ} \mathrm{C}$ was observed.

From combined phylogenetical analysis based on ITS, BT2 and TE1-1 sequences (Fig. 16), as well as from separate ITS, BT2 and TEF-1 analyses (not shown) Ukrainian specimen of Exophiala belongs to the Exophiala alcalophila branch with the highest level of bootstrap support. Our data confirm the previous results of de Hoog et al. (2011) that Exophiala alcalophila belongs to the Exophiala angulospora complex, which is positioned in out-position to the SSU Exophiala salmonis-clade. After our data the Exophiala angulospora complex includes E. angulospora, E. alcalophila, and E. halophila, as well as E. jeanselmei, E. oligosperma, E. xenobiotica, and E. nigra. The Exophiala salmonis-clade was presented by E. salmonis, E. equina, E. pisciphila, E. psychrophila, E. opportunistica, E. cancerae, and E. brunnea in our study. Furthermore Exophiala lecanii-cornii found to be in separate out-position to the Exophiala salmonis-clade and to the Exophiala angulospora complex if E. mesophila and E. castellanii are selected as out-group (Fig. 16).

\section{CONCLUSIONS}

Thus, status of black melanin-containing yeast-like fungus Exophiala alcalophila isolated from microorganism complex of hermetic damaged in conditions of indoor high humidity in Kiev, Ukraine, recently (newly) recorded for

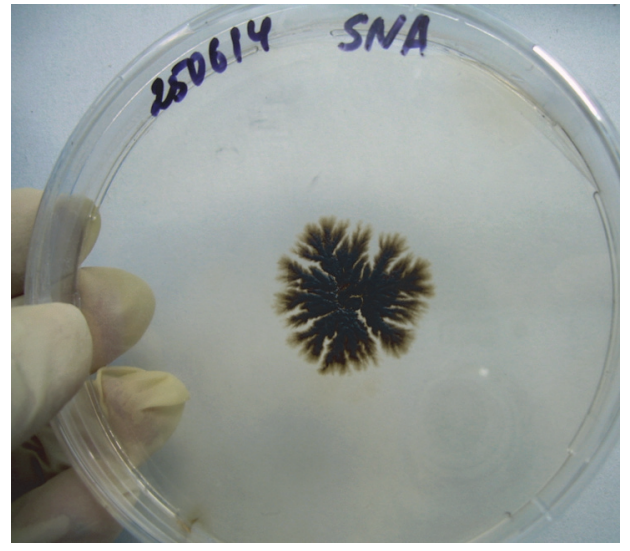

Fig. 14. Radiating / radially ramified colony of Exophiala alcalophila FCKU 304 on solid SNA medium

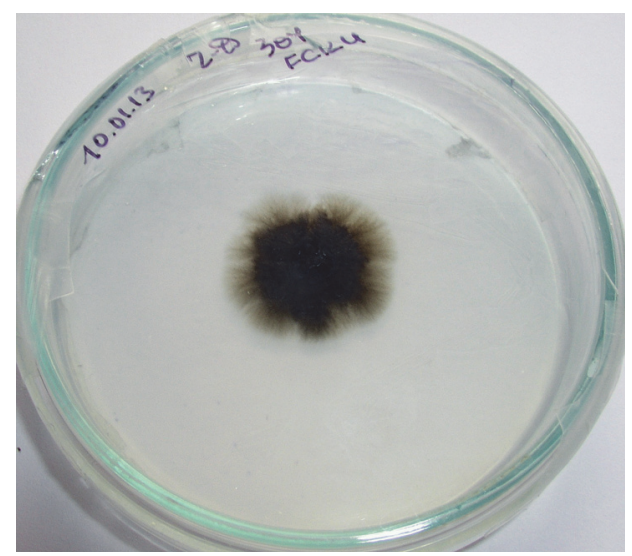

Fig. 15. General habit of colony of Exophiala alcalophila FCKU 304 on solid CZD medium 
Ukraine, is proved by combined phylogenetical analysis based on sequences of the internal transcribed spacer 1 (ITS1), the 5.8S gene and the internal transcribed spacer 2 (ITS2) nrDNA, beta-tubulin gene and translation elongation factor 1-alpha gene. Sequences of the mentioned genes of Ukrainian specimen are for the first time submitted to GenBank.

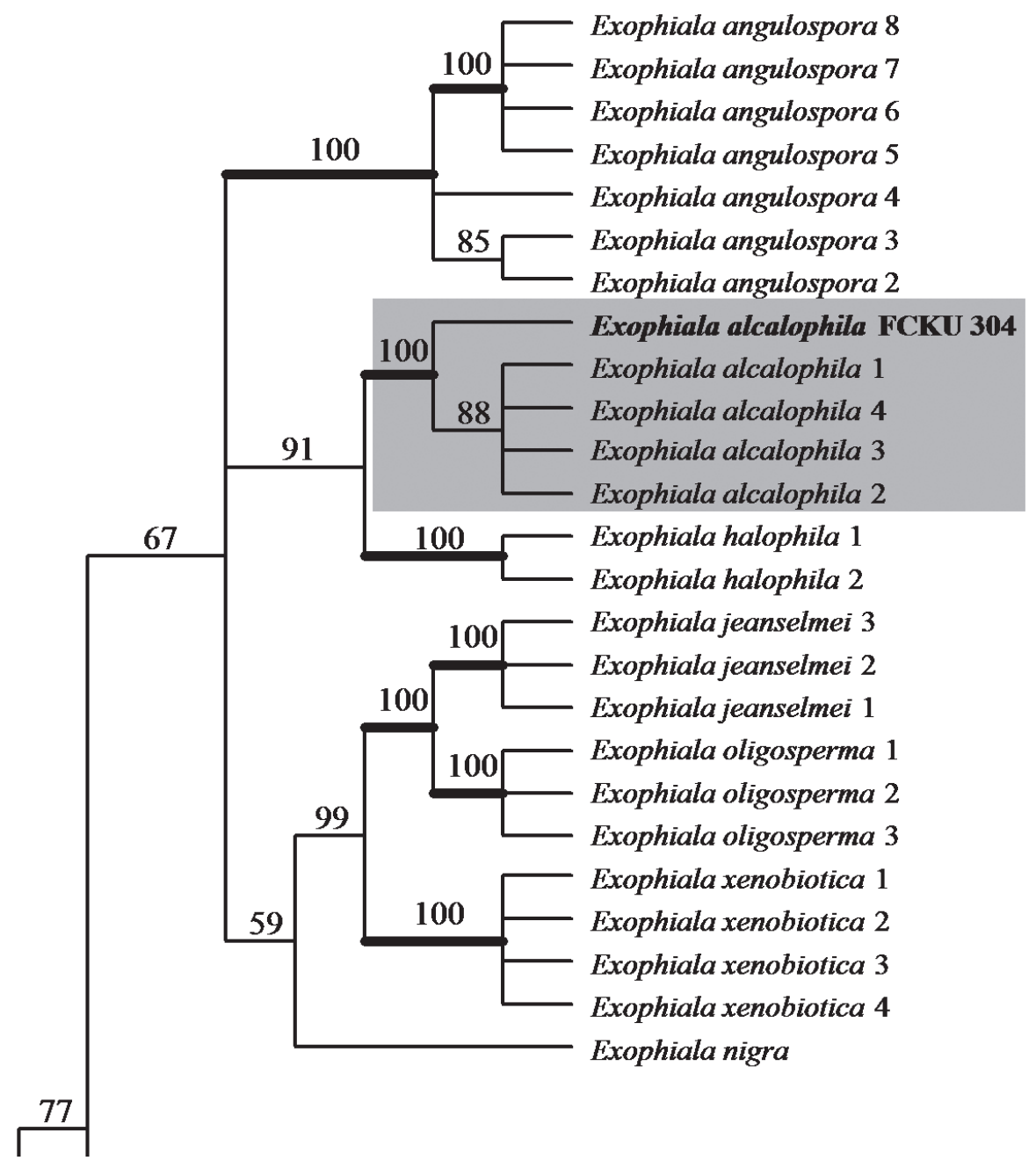

Fig. 16. Phylogeny of the SSU-based Exophiala salmonis-clade (sensu de Hoog et al. 2011) obtained from a combined ML analysis based on ITS, TE-1 and BT2 gene sequences. Supported branches are drawn in bold. The tree was rooted with Exophiala mesophila and E. castellanii 


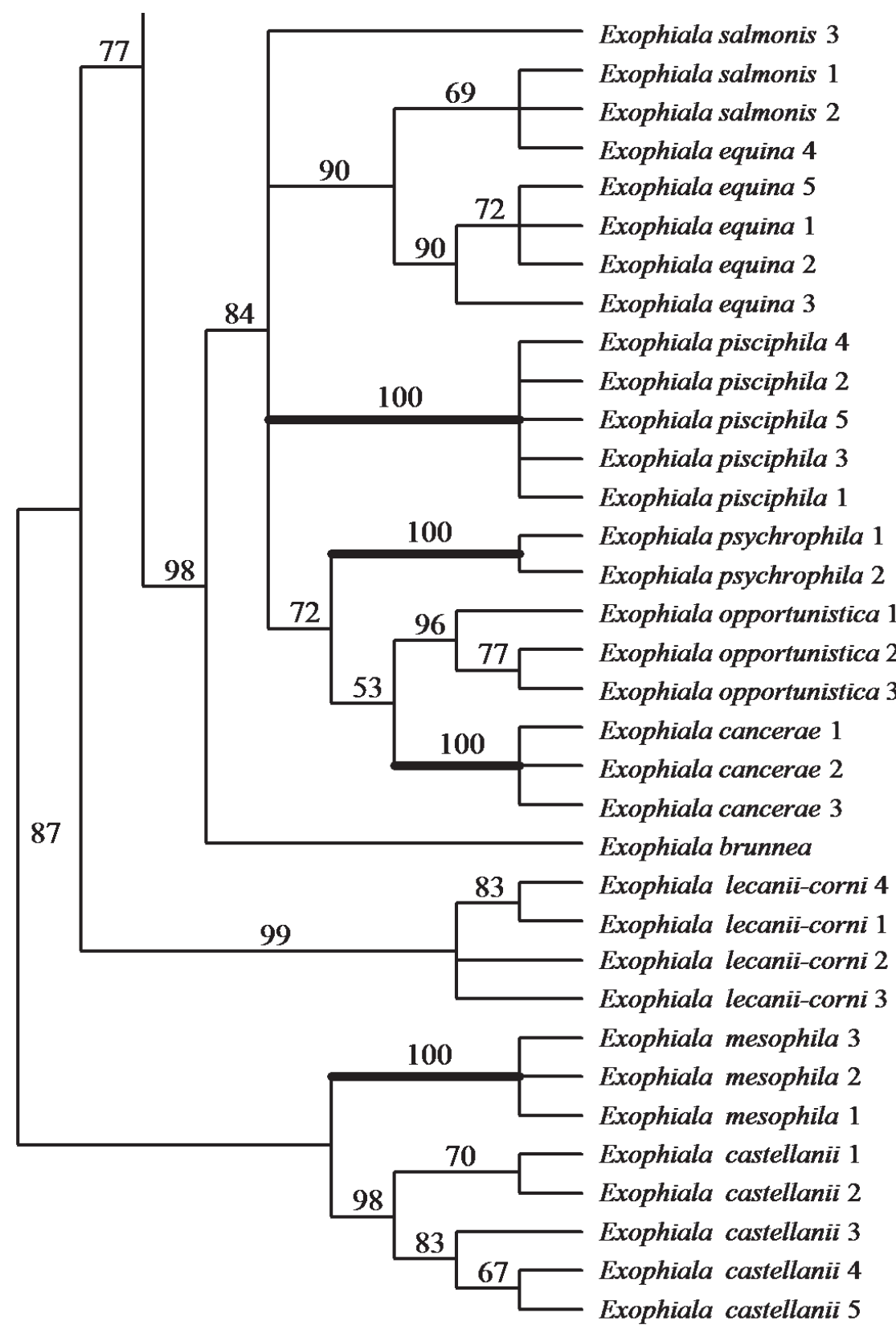

Fig. 16 (continued). Phylogeny of the SSU-based Exophiala salmonis-clade (sensu de Hoog et al. 2011) obtained from a combined ML analysis based on ITS, TE-1 and BT2 gene sequences. Supported branches are drawn in bold. The tree was rooted with Exophiala mesophila and E. castellanii 
Acknowledgements - We are thankful to L. Lőkös (Budapest, Hungary) for valuable comments on manuscript and improvements of English, as well as to Pavlyna P. Zelena (Kiev, Ukraine) for help during work with microbiological analyser, and to Vitalij I. Sapsay (Kiev, Ukraine) for help during work with SEM. SK is thankful to Ministry of Education and Sciences of Ukraine (M/90-2015 and M/34-2016) as well as Korean Brian Pool Program (161S4-3-1659) for financial support in parts.

\section{REFERENCES}

Attili-Angelis, D., Duarte, A., Pagnocca, F., Nagamoto, N., de Vries, M., Stielow, J. B. and de Hoog, G. (2014): Novel Phialophora species from leaf-cutting ants (tribe Attini). Fungal Divers. 65: 65-75. http://dx.doi.org/10.1007/s13225-013-0275-0

Crous, P. W., Verkley, G. J. M., Groenewald, J. Z. and Samson, R. A. (eds) (2009): Fungal biodiversity. - CBS Laboratory Manual Series, Vol. 1. CBS-KNAW Fungal Biodiversity Centre, Utrecht, 269 pp.

de Hoog, G. S., Zeng, J. S., Harrak, M. J. and Sutton, D. A. (2006): Exophiala xenobiotica sp. nov., an opportunistic black yeast inhabiting environments rich in hydrocarbons. Antonie van Leeuwenhoek 90: 257-268. http://dx.doi.org/10.1007/s10482-006-9080-z

de Hoog, G. S., Vicente, V., Caligiorne, R. B. Kantarcioglu, S., Tintelnot, K., Gerrits van den Ende, A. H. G. and Haase, G. (2003): Species diversity and polymorphism in the Exophiala spinifera clade containing opportunistic black yeast-like fungi. - J. Clin. Microbiol. 41(10): 4767-4778. http://dx.doi.org/10.1128/JCM.41.10.4767-4778.2003

de Hoog, G. S., Vicente, V. A., Najafzadeh, M. J., Harrak, M. J., Badali, H. and Seysdmousavi, S. (2011): Waterborne Exophiala species causing disease in cold-blooded animals. - Persoonia 27: 46-72. http://dx.doi.org/10.3767/003158511X614258

de Hoog, G. S., Queiroz-Telles, F., Haase, G., Fernandez-Zeppenfeldt, G., Angelis, D. A., Gerrits Van Den Ende, A. H. G., Matos, T., Peltroche-Llacsahuanga, H., PizziraniKleiner, A. A., Rainer, J., Richard-Yegres, N., Vicente, V. and Yegres, F. (2000): Black fungi: clinical and pathogenic approaches. - Med. Mycol. 38 (Suppl. 1): 243-250. http:// dx.doi.org/10.1080/mmy.38.s1.243.250

Döğen, A., Kaplan, E., Öksüz, Z., Serin, M. S., Macit, I. and de Hoog, G. S. (2013): Dishwashers are a major source of human opportunistic yeast-like fungi in indoor environments in Mersin, Turkey. - Med. Mycol. 51(5): 493-498. http://dx.doi.org/10.3109/ 13693786.2012.738313

Gardes, M. and Bruns, T. D. (1993): ITS primers with enhanced specificity for basidiomycetes - application to the identification of mycorrhizae and rusts. - Mol. Ecol. 2: 113118. http://dx.doi.org/10.1111/j.1365-294x.1993.tb00005.x

Gostincar, C., Grube, M. and Gunde-Cimerman, N. (2011): Evolution of fungal pathogens in domestic environments? - Fungal Biol. 115(10): 1008-1018. http://dx.doi.org/10.1016/j. funbio.2011.03.004

Gunde-Cimerman, N. and Zalar, P. (2011): Dishwasher and car wash: man-made environments accommodating human opportunistic black yeasts. - Emerging Potential of Black Yeasts, Curitiba, http://www.blackyeast.org/Curitiba/download/files/Nina_Gunde-Cimerman.pdf. 
Hageskal, G., Knutsen, A. K., Gaustad, P., de Hoog, G. S. and Skaar, I. (2006): Diversity and significance of mold species in Norwegian drinking water. - Appl. Environ. Microbiol. 72(12): 7586-7593. http://dx.doi.org/10.1128/AEM.01628-06

Hamada, N. (2013): Black yeasts in washing machines and dishwashers: - Electronic Abstracts, 5th ISHAM meeting, "Black Yeasts and Chromoblastomycosis", Guangzhou, China, 29 November-1 December, p. 12. http://www.blackyeast.org/Guangzhou/Download/Abstract.pdf

Hamada, N. and Abe, N. (2010): Comparison of fungi found in bathrooms and sinks. - Biocontrol Sci. 15(2): 51-56. http://dx.doi.org/10.4265/bio.15.51

Kantarcloglu, A. S. and de Hoog, G. S. (2004): Infections of the central nervous system by melanized fungi: a review of cases presented between 1999 and 2004. - Mycoses 47(1-2): 4-13. http://dx.doi.org/10.1046/J.1439-0507.2003.00956.x

Kondratyuk, T. A. (2010): Biofilm on synthetic polymeric materials in conditions of high humidity rooms. - Immunopath. Allergol. Infectol. 1: 65-66. (In Russian).

Kondratyuk, T. (2013): Black yeast-like fungi Exophiala alcalophila Goto et Sugly from hermetic damaged in conditions of indoor high humidity. - Modern Phytomorph. 3: 225-229.

Kondratyuk, T.andKalinichenko,A.(2014):Influenceofessentialoilsand polyhexamethylene guanidine on black yeast-like fungus Exophiala alcalophila. - Visnyk Kyiv. Nat. Univ. Tarasa Shevchenka, Biol. 68(3): 75-79. http://dx.doi.org/10.17721/1728_2748.2014.68.75-79

Kondratyuk, T. and Kalinichenko, A. (2015): Structural-functional reorganization of dimorphous black yeast-like fungi Exophiala alcalophila under influence of plant essential oils. - Visnyk Kyiv. Nat. Univ. Tarasa Shevchenka, Biol. 70(2): 42-46. http://dx.doi. org/10.17721/1728_2748.2015.70.42-46

Kondratyuk, T. O., Jeong, M.-H., Hur, J.-S. and Kondratyuk, S. Ya. (2013): Phylogenetic analysis of microscopic fungi of the genera Cladosporium and Exophiala after nuclear DNA. - In: Kondratyuk, S. Y. (ed.): Molecular phylogeny and recent taxonomy of terrestrial spore plants. 'Scientific book' project. Naukova dumka, Kyiv, pp. 80-94.

Lian, X. and de Hoog, G. S. (2010): Indoor wet cells harbour melanized agents of cutaneous infection. - Med. Mycol. 48(4): 622-628. http://dx.doi.org/10.3109/13693780903405774

Matos, T., de Hoog, G. S., de Boer, A. G., de Crom, I. and Haase, G. (2002): High prevalence of the neurotrope Exophiala dermatitidis and related oligotrophic black yeasts in sauna facilities. - Mycoses 45(9-10): 373-377. http://dx.doi.org/10.1046/j.14390507.2002.00779.x

Nishimura, K., Miyaji, M., Taguchi, H. and Tanaka, R. (1987): Fungi in bathwater and sludge of bathroom drainpipes. 1. Frequent isolation of Exophiala species. - Mycopathol. 97(1): 17-23. http://dx.doi.org/10.1007/bf00437326

Ozerskaya, S. M., Ivanushkina, N. Y. and Kochkina, G. A. (2007): Pathogenic fungi: the categorization of biological risk and diversity. - In: Sergeev, Y. V. (ed.): Advances in medical mycology. Vol. 1. National Academy of Mycology, Moscow, pp. 268-282.

Prenafeta-Boldu, F. X., Summerbell, R. and de Hoog, G. S. (2006): Fungi growing on aromatic hydrocarbons: biotechnology's unexpected encounter with biohazard? - FEMS Microbiol. Rev. 30(1): 109-130. http://dx.doi.org/10.1111/j.1574-6976.2005.00007.x

Rimawi, B. H., Rimawi, R. H., Mirdamadi, M., Steed, L. L., Marchell, R., Sutton, D. A., Thompson, E. H., Wiederhold, N. P., Lindner, J. R. and Boger, M. S. (2013): A case of Exophiala oligosperma successfully treated with voriconazole. - Med. Mycol. Case Rep. 2: 144-147. http://dx.doi.org/10.1016/j.mmcr.2013.08.003 
Samson, R. A., Hoekstra, E. S. and Frisvad, J. C. (2004): Introduction to food and airborne fungi. 7th ed. - Ponsen and Looyen, Wageningen, $389 \mathrm{pp}$.

Sutton, D. A., Fothergill, A. W. and Rinaldi, M. G. (1998): Guide to clinically significant fungi. - Williams and Wilkins, Baltimore, $471 \mathrm{pp}$.

Sutton, D. A., Fothergill, A. W. and Rinaldi M. G. (2001): Handbook of pathogenic and opportunistic fungi. - Mir, Moscow, 468 pp. [in Russian]

Sterflinger, K. (2006): Black yeasts and meristematic fungi: ecology, diversity and identification.In: Péter, G. and Rosa, C. (eds): The yeast handbook. Biodiversity and ecophysiology of yeasts. Springer, Berlin, Heidelberg, pp. 501-514. http://dx.doi.org/10.1007/3-54030985-3_20

Vitale, R. G. and de Hoog, G. S. (2002): Molecular diversity, new species and antifungal susceptibilities in the Exophiala spinifera clade. - Med. Mycol. 40(6): 545-556. http:// dx.doi.org/10.1080/714031149

White, T. J., Bruns, T., Lee, S. and Taylor, J. (1990): Amplification and direct sequencing of fungal ribosomal RNA genes for phylogenetics. - In: Innis, M. A., Gelfand, D. H., Sninsky, J. J. and White, T. J. (eds): PCR protocols: a guide to methods and applications. 38. Academic Press, New York, pp. 315-322.

Woo, P. C. Y., Ngan, A. H. Y., Tsang, C. C., Ling, I. W. H., Chan, J. F. W., Leung, S.-Y., Yuen, K.-Y. and Lau, S. K. P. (2013): Clinical spectrum of Exophiala infections and a novel Exophiala species, Exophiala hongkongensis. - J. Clin. Microbiol. 51(1): 260-267. http://dx.doi.org/10.1128/JCM.02336-12

Zalar, P., Novak, M., de Hoog, G. S. and Gunde-Cimerman, N. (2011): Dishwashers, a man-made ecological niche accommodating human opportunistic fungal pathogens. - Fungal Biol. 115(10): 997-1007. http://dx.doi.org/10.1016/j.funbio.2011.04.007

Zeng, J. and de Hoog G. S. (2008): Exophiala spinifera and its allies: diagnostics from morphology to DNA barcoding. - Med. Mycol. 46(3): 193-208. http://dx.doi. org/10.1080/13693780701799217 